\title{
Lithostratigraphy of the Nawakot Complex (Lesser Himalayan Sequence) from Malekhu area (south-west) to Syabrubensi area (north-east) along the Trishuli River, central Nepal Himalaya
}

\author{
Santa Man Rai \\ Department of Geology, Tri-Chandra Campus \\ Tribhuvan University, Ghantaghar, Kathmandu, Nepal \\ (Email: santaman_rai2010@yahoo.com)
}

\begin{abstract}
All formations (Kuncha Formation, Fagfog Quartzite, Dandagoan Phyllite, Nourpul Formation, Dhading Dolomite of the Lower Nawakot Group and Benighat Slate, Malekhu Limestone and Robang Formation of the Upper Nawakot Group) of the Nawakot Complex are well exposed along the Malekhu - Thopal Khola and Galchi - Kaljeri sections, west of the Kathmandu Valley. The Phalangu Khola and Syabrubensi sections, north of the Kathmandu Valley do not show the exposures of all formations (exposures of the Kuncha Formation, Fagfog Quartzite, and Benighat Slate only). The stratigraphic sequences from the Kuncha Formation to Dhading Dolomite (Lower Nawakot Group) along the Malekhu-Thopal Khola section are overturned, showing the younging strata to the deeper sections shown by the sedimentary structures (ripple marks, mudcracks, etc.) and stromatolites. These overturned sequences could be related to the development of the post Main Central Thrust (MCT)/ Mahabharat Thrust (MT) deformational structure (Gorkha - Pokhara anticlinorium, Likhu Khola anticline). The stratigraphic sequences are normal in the formations of the Upper Nawakot Group along the Malekhu-Thopal Khola section. This normal sequence can be also observed along the Galchi - Kaljeri, Phalangu Khola and Syabrubensi sections. In the northern part of the study area along the Likhu Khola, Tadi Khola, Phalangu Khola and Syabrubensi sections, the rocks of the Benighat Slate just below the MCT are highly sheared, deformed, metamorphosed with the development of the garnet and staurolite (medium amphibolite facies metamorphism) due to the movement of the MCT. However, these minerals are not developed in the Robang Formation (immediate below the MT) along the Malekhu - Thopal Khola and Galchi - Kaljeri sections. This formation could be caused by shallow depth metamorphism (green-schist to lower amphibolite facies) along the movement of the MT.
\end{abstract}

Keywords: Lithostratigraphy, Nawakot Complex, central Nepal Himalaya

Received: 15 January 2011

revision accepted: 25 March 2011

\section{INTRODUCTION}

The Himalayan chain is the result of the collision between the Indian and Eurasian continents during the Eocene period. The continuous subduction of the Indian continent below the Eurasian continent resulted the different intracontinental normal and thrust faults (South Tibetan Detachment System, Main Central Thrust, Main Boundary Thrust and Main Frontal Thrust) from north to south, respectively. The continuous subduction of the Indian continent has resulted the changing in topography, climate, geomorphology in the Himalaya. The different normal and thrust faults separate the Himalaya into the different tectonic zones, i.e., Tibetan-Tethys Himalaya, Higher Himalayan Crystallines, Lesser Himalayan Sequence and Siwaliks from north to south, respectively (Fig. 1). The Main Central Thrust (MCT), a major thrust fault separates the Lesser Himalayan Sequence from the Higher Himalayan Crystallines. This thrust is a major syn-to post collisional thrust fault extending in the Himalaya (Gansser 1964, Le Fort 1975, Pêcher 1989). The amphibolite to granulite facies metamorphic rocks of the Higher Himalayan Crystallines overlie the green-schist to lower amphibolite facies metamorphic and sedimentary rocks of the Lesser Himalayan Sequence along the MCT. The inverse metamorphism is well recorded in the Lesser Himalayan Sequence supported by the field evidence and thermobarometric studies (Le Fort 1975, Pêcher 1978, Inger and Harris 1992, Macfarlane 1995, Rai et al. 1998).

The main objective of this study is to correlate the lithostratigraphy of the different sections of the Nawakot Complex from Malekhu to Syabrubensi area, along the Trishuli River, central Nepal (Fig. 2). 


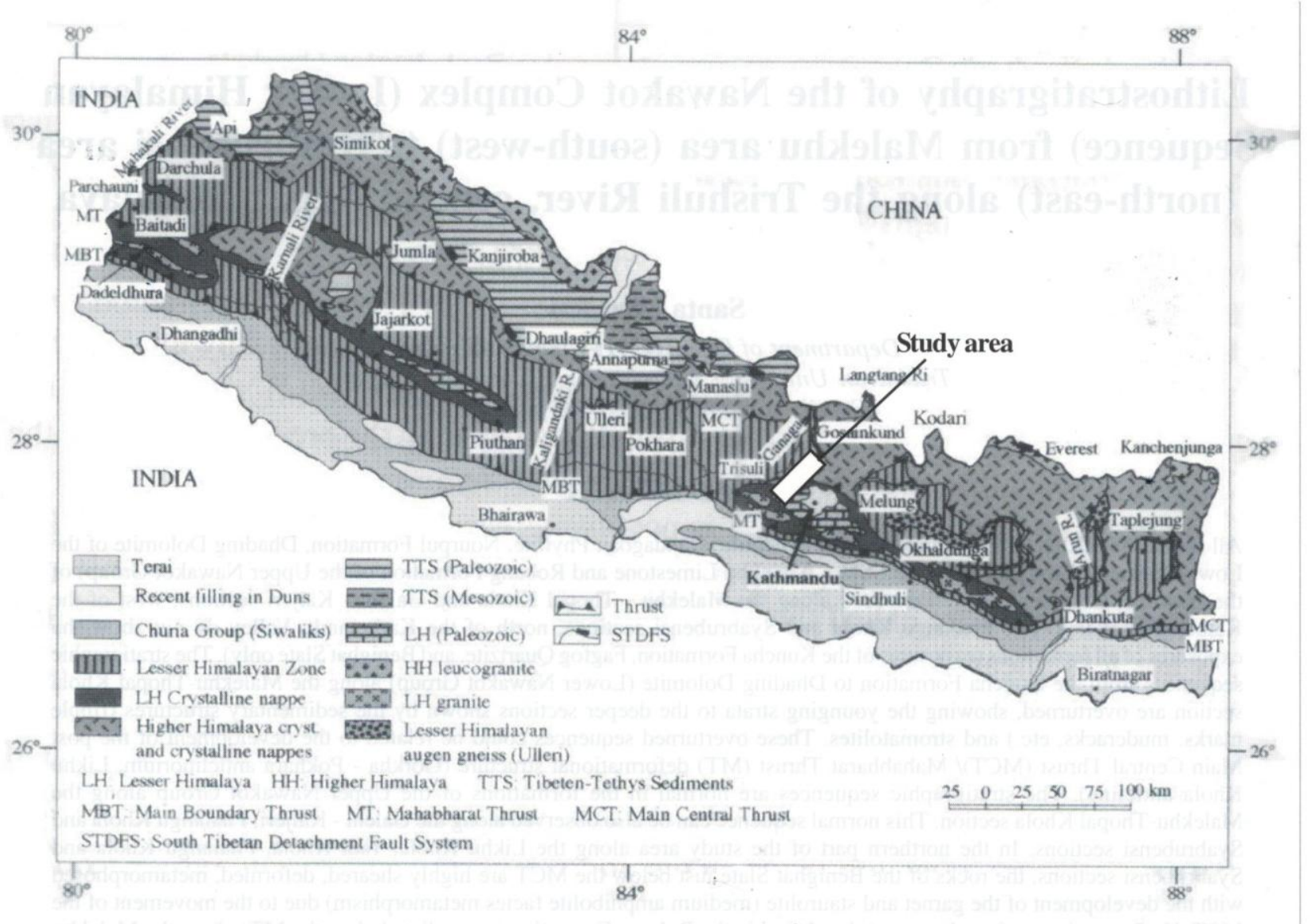

Fig. 1: Geological map of the Nepal Himalaya (Upreti and Le Fort 1999)

\section{GEOLOGICAL SETTING}

The study area belongs to the Lesser Himalayan Sequence separated from the Higher Himalayan Crystallines by the Main Central Thrust (MCT) in the northern area of the Kathmandu Valley or Mahabharat Thrust (MT) in the east, south and west of the Kathmandu Valley. The MT is considered as the southern prolongation of the MCT in the east, south and western part of the Kathmandu Complex (Stöcklin and Bhattarai 1977, Stöcklin 1980, Pandey et al. 1995, Johnson et al. 2001). The Lesser Himalayan rocks can be correlated either with the Midland Formation, central west Nepal (Le Fort 1975, Pêcher 1978, Colchen et al. 1986), the Nawakot Complex in the central Nepal (Stöcklin and Bhattarai 1977, Stöcklin 1980) or the Kaligandaki Supergroup, western Nepal (Sakai 1985). The rocks of the Nawakot Complex are overlain by the Kathmandu Complex along the MT. The rocks of the Kathmandu Complex are considered as the rocks of the Higher Himalayan Crystallines and Tibetan-Tethys Himalaya (Stöcklin and Bhattarai 1977, Stöcklin 1980). The rocks of the Nawakot Complex are continuously exposed along the Trishuli River from Malekhu area (south-west) to Syabrubensi area (north-east) (Fig. 2). In this study the observations were carried out along the Malekhu - Thopal
Khola, Galchi - Kaljeri, Phalangu Khola and Syabrubensi sections from south to the north, respectively (Fig. 2). Stratigraphically, all formations of the Nawakot Complex (Lesser Himalayan Sequence) from bottom to top can be observed along the Malekhu - Thopal Khola section (Fig. 3) and Galchi - Kaljeri section. The Nawakot Complex is divided into two groups (Lower and Upper) separated by an erosional unconformity (Stöcklin and Bhattarai 1977, Stöcklin 1980). The Lower Nawakot Group from bottom to top consists of the Kuncha Formation, Fagfog Quartzite, Dandagaon Phyllite, Nourpul Formation and Dhading Dolomite in ascending order. Similarly, the Upper Nawakot Complex is also divided into the Benighat Slate, Malekhu Limestone and Robang Formation from lower to upper sections.

\section{LITHOSTRATIGRAPHY}

The lithostratigraphy of the study area is described below on the basis of field observations following the lithostratigraphy established by Stöcklin and Bhattarai (1977), Stöcklin (1980). A stratigraphic correlation is established from the Malekhu - Thopal Khola, Galchi - Kaljeri, Phalangu Khola and Syabrubensi sections on the basis of 


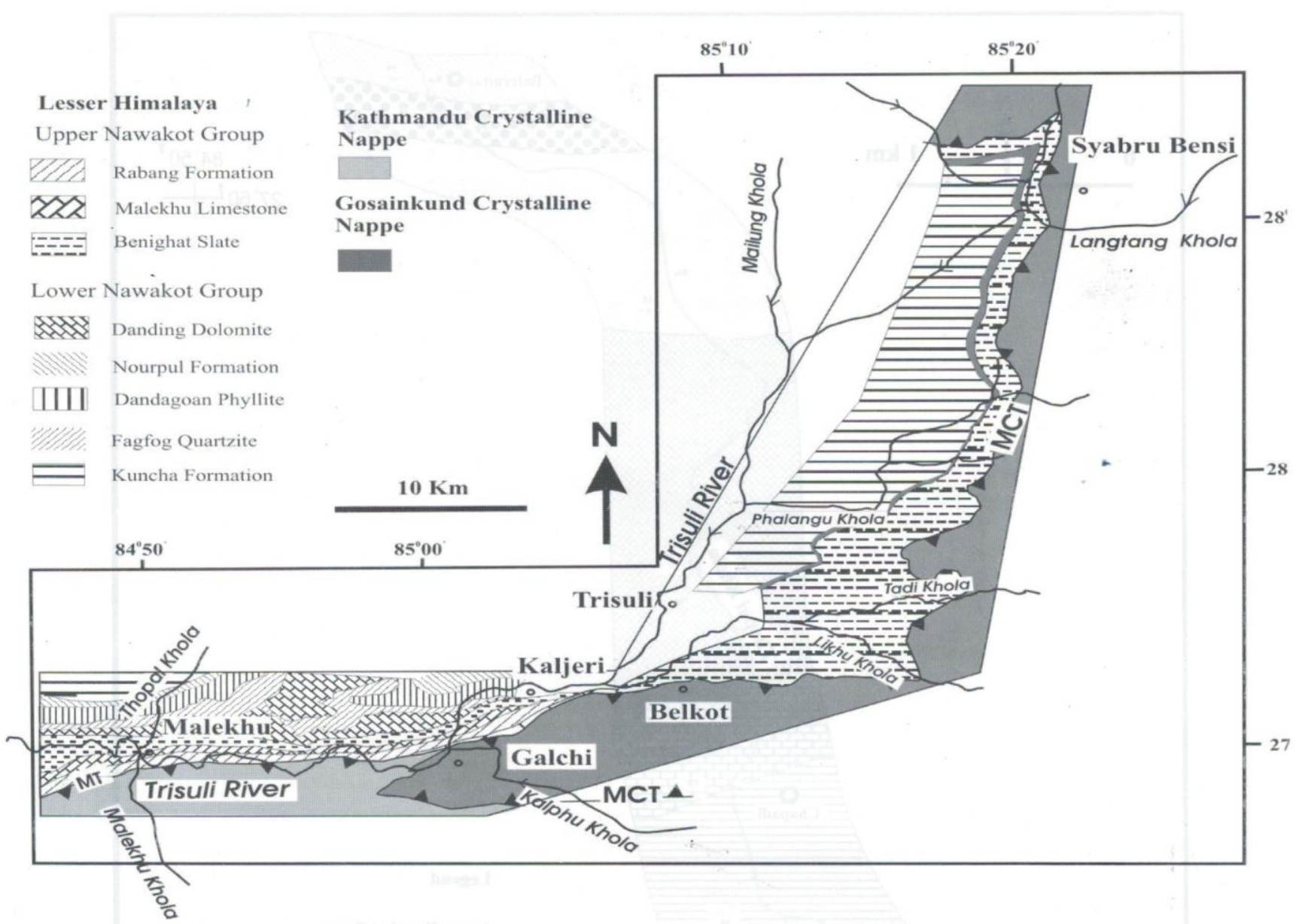

Fig. 2: Geological map of study area (Stöcklin 1980; Rai 1998, 2001)

field observations of lithology (Table 1). A geological map prepared along the Malekhu-Thopal Khola section shows all formations of the Nawakot Complex (Fig. 3).

\section{Lower Nawakot Group, Nawakot Complex}

\section{Kuncha Formation}

This formation, the oldest unit of the Himalaya is well exposed along the Malekhu - Thopal Khola, Phalangu Khola and Syabrubensi sections (Figs. 2, 3 and 4). But this formation is also well exposed to the north of Kaljeri village (Galchi - Kaljeri section) crossing the Trishuli River (Fig. 2). This formation consists of monotonous lithology containing greenish-grey phyllite, quartzitic phyllite, phyllitic metasandstone, gritstone, micro-conglomerate, black schist occasionally with bands of amphibolite. This formation can be correlated with the Dhunche Schist, Thangjet Schist and Goljhong Schist of Syabrubensi area (Macfarlane et al. 1992). Arita et al. (1973) noted out the amphibolite bands intercalated within greenish-grey phyllite in central Nepal. Sometimes, thin layers of micro- conglomerate are intercalated within phyllite and schist. Such type of lithology is exposed in the central Nepal (Pêcher 1978, Stöcklin 1980, Sharma and Kizaki 1989). Along the Phalangu Khola section, micro-conglomerate (about thickness of $12 \mathrm{~cm}$ ) intercalated with schist consists of smoky colored, rounded quartz (up to $5 \mathrm{~mm}$ diameter), feldspar, two mica and tourmaline as accessory mineral. The micro-conglomerate shows the graded beds and cross bedded structures. Its basal contact with the schist is sharp while the contact with overlying schist is transitional. Quartz, muscovite, biotite, plagioclase, tourmaline and opaque are the minerals. The color of the quartz is violet and blue in the thin section study, characteristic of the Kuncha Formation. Such type of quartz was also observed in the central Nepal (Pêcher 1978, Stöcklin 1980, Arita 1983, Sharma and Kizaki 1989). The NNE mineral lineation marked by two mica and chlorite in this formation shows top to south sense of shearing. Crenulation cleavages are well marked showing the polyphase deformation. The sediments of the Kuncha Formation were deposited in the lower part of the neritic zone of the marine environment. 


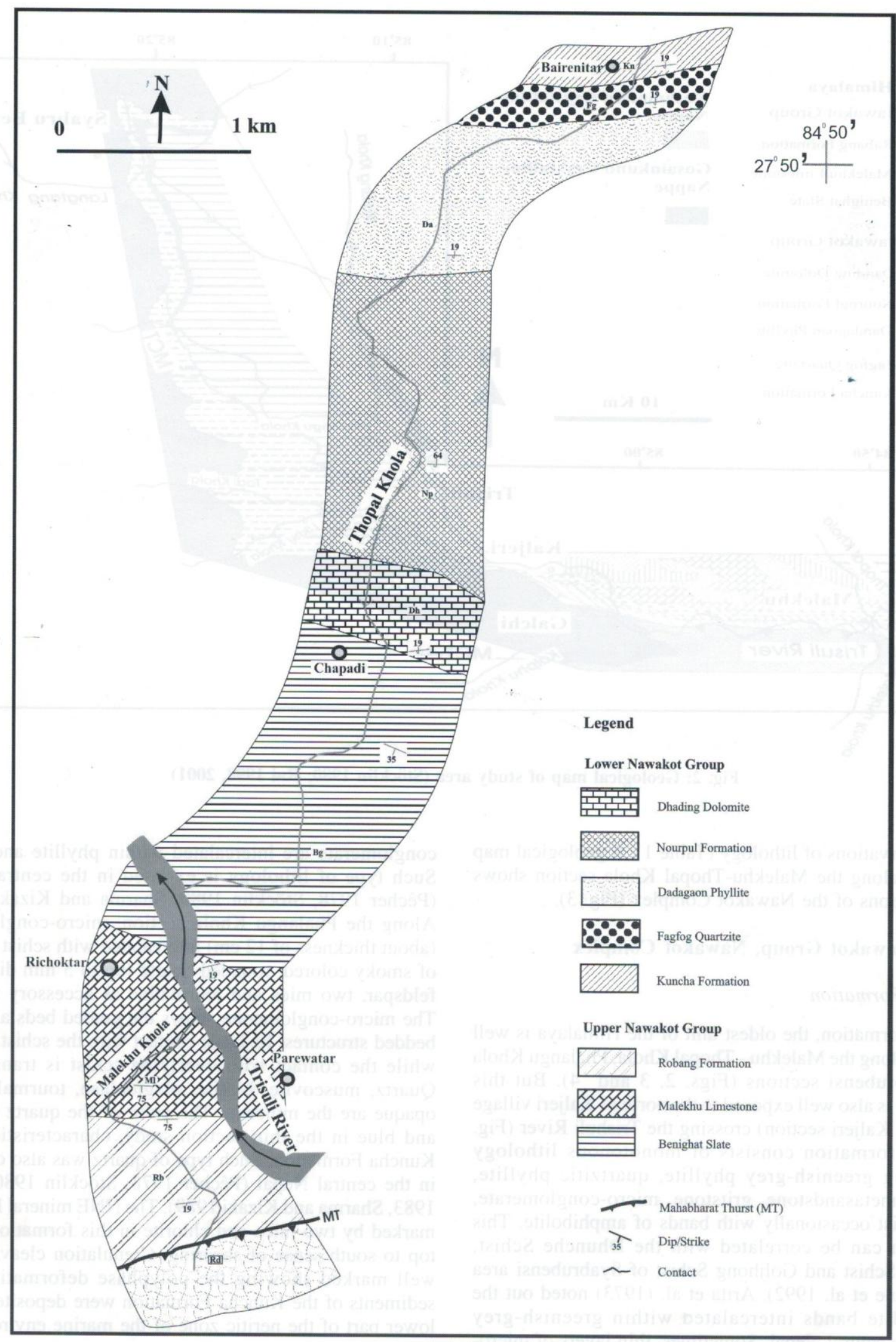

Fig. 3: Geological map of Malekhu-Thopal Khola section, central Nepal 
Table 1: Lithostratigraphic correlation of study area

\begin{tabular}{|c|c|c|c|c|}
\hline Malekhu-Thopal Khola & Galchi-Kaljeri & Phalangu Khola & Syabrubensi & Age \\
\hline Robang Formation & Robang Formation & \multirow{6}{*}{ Benighat Slate } & \multirow{6}{*}{ Benighat Slate } & \multirow{8}{*}{$\begin{array}{l}\text { Pre- } \\
\text { Cambrian } \\
\text { to } \\
\text { Early } \\
\text { Paleozoic }\end{array}$} \\
\hline Malekhu Limestone & Malekhu Limestone & & & \\
\hline Benighat Slate & Benighat Slate & & & \\
\hline Dhading Dolomite & Dhading Dolomite & & & \\
\hline Nourpul Formation & Nourpul Formation & & & \\
\hline Dandagaon Phyllite & Dandagaon Phyllite & & & \\
\hline Fagfog Quartzite & Fagfog Quartzite & Fagfog Quartzite & Fagfog Quartzite & \\
\hline Kuncha Formation & Kuncha Formation & Kuncha Formation & Kuncha Formation & \\
\hline
\end{tabular}

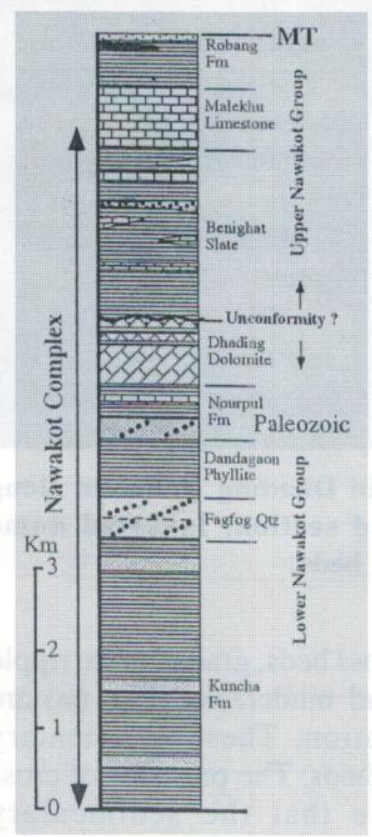

(a)

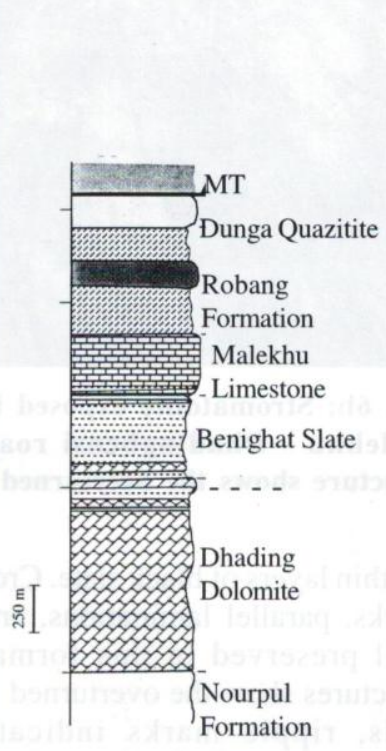

(b)

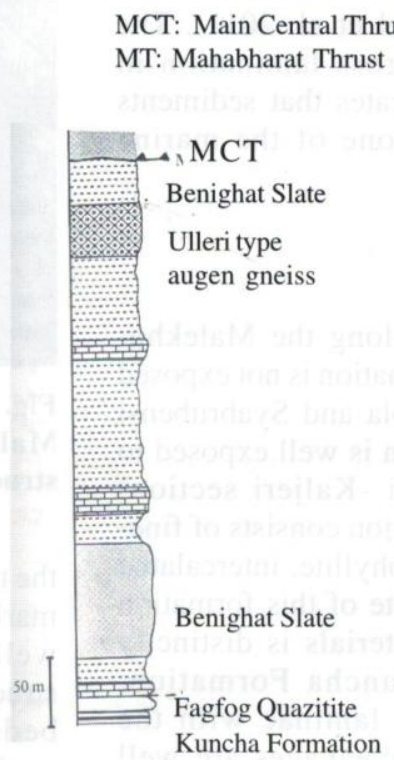

(c)

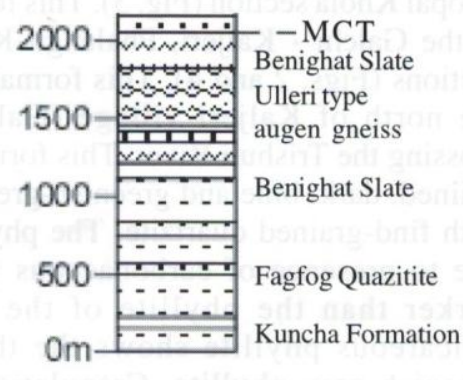

(d)

Fig. 4: Lithostratigraphic column of study area; (a) Nawakot Complex, central Nepal (Stöcklin 1980), (b) Galchi - Kaljeri section, (c) Phalangu Khola section and (d) Syabrubensi area

\section{Fagfog Quartzite}

This formation is well exposed along the MalekhuThopal Khola, Phalangu Khola and Syabrubensi sections (Figs. 2 and 4). This formation is also well exposed to the north of Kaljeri village (Galchi - Kaljeri section) crossing the Trishuli River. This formation consists of fine to medium-grained, milky orthoquartzite intercalated with fine-grained phyllite, greenish-grey schist. Along the Phalangu Khola section, thin bands of marble are also intercalated within the quartzite. The sedimentary structures such as ripple marks, gradded and cross beds show the normal sequence (Stöcklin and Bhattarai 1977, Pêcher 1978, Stöcklin 1980, Arita 1983, Sakai 1985, Sharma and Kizaki 1989). In contrast, the sedimentary structures exposed in this formation along the Malekhu-Thopal Khola 


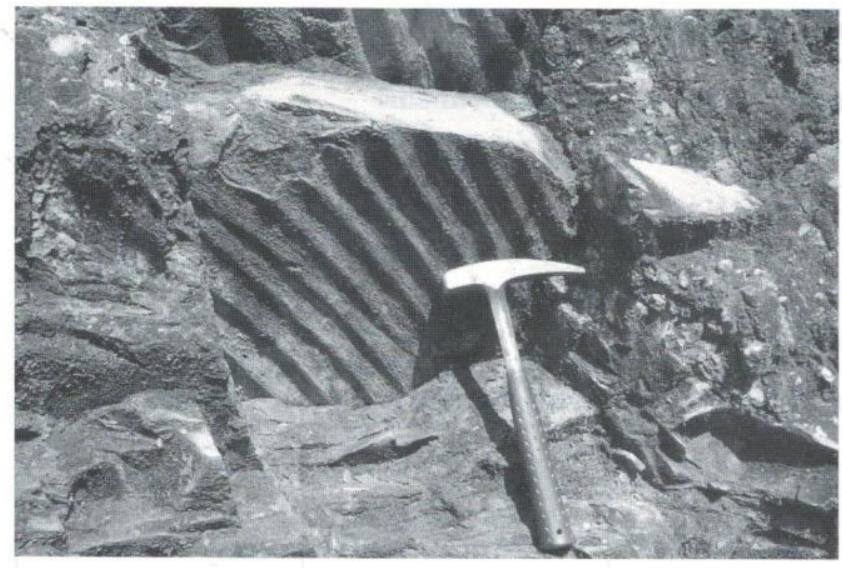

Fig. 5: Ripple marks exposed in Fagfog Quartizte along the Malekhu - Dhadingbensi road section. The ripples show overturned strata.

section show the overturned beds (younger strata on the deeper section) (Fig. 5). In study area, intercalation of the metabasite was not observed within the orthoquartzite, however, it was described in the central Nepal (Upreti and Merh 1978, Upreti et al. 1980, Sakai 1985, Colchen et al. 1986, Paudel and Dhital 1996, Paudel et al. 2011). The presence of the ripple marks and cross lamination in medium-grained, white quartzite indicates that sediments were deposited within the neritic zone of the marine environment.

\section{Dandagaon Phyllite}

This formation is well exposed along the MalekhuThopal Khola section (Fig. 3). This formation is not exposed in the Galchi - Kaljeri, Phalangu Khola and Syabrubensi sections (Figs. 2 and 4). This formation is well exposed to the north of Kaljeri village (Galchi -Kaljeri section) crossing the Trishuli River. This formation consists of finegrained, dark, blue and greenish-grey phyllite, intercalated with find-grained quartzite. The phyllite of this formation due to presence of carbonaceous materials is distinctly darker than the phyllite of the Kuncha Formation. Calcareous phyllite shows the thin laminae with the greenish-grey phyllite. Crenulation cleavages are well developed in the phyllite showing polyphase deformations along the Malekhu-Dhadingbensi road section. The argillaceous sediments of the Dandagaon Phyllite show that the deposition was occurred in the lower part of the neritic zone of the marine environment.

\section{Nourpul Formation}

This formation is well exposed along the Malekhu Thopal Khola and Galchi -Kaljeri sections (Rai 1998). This formation is not exposed in the Phalangu Khola and Syabrubensi sections (Figs. 2 and 4). This formation consists of fine-grained, multivarigated quartzite intercalated with greenish-grey phyllite and schist. Few meter thick calcareous quartzite is also intercalated within

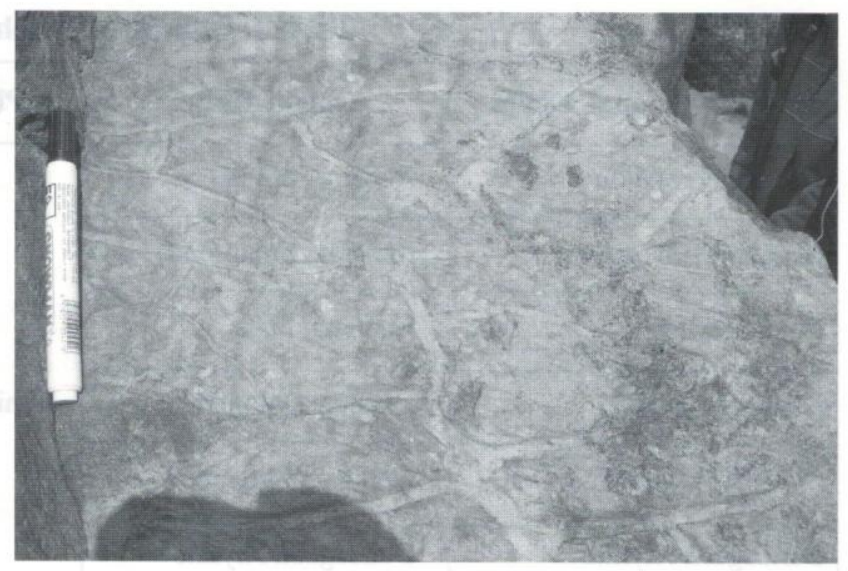

Fig. 6a: Mudcraks exposed in the Nourpul Formation along the Malekhu - Dhadingbensi road section

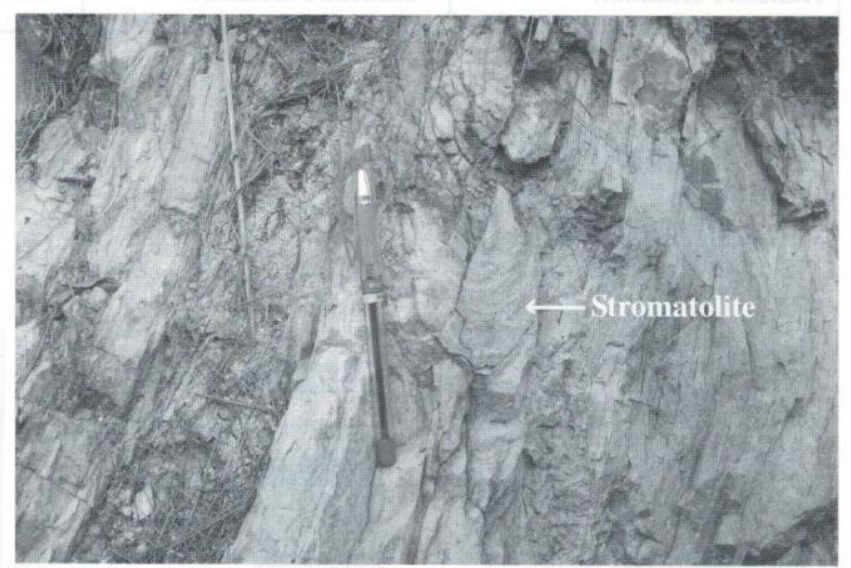

Fig. 6b: Stromatolite exposed in Dhading Dolomite along Malekhu - Dhadingbensi road section. Inverted dome structure shows the overturned beds.

the thin layers of black slate. Cross beds, graded beds, ripple marks, parallel laminations, and mudcracks (Fig. 6a) are well preserved in this formation. These sedimentary structures show the overturned beds. The presence of cross beds, ripple marks indicate that the sedimentary environment of this formation is shallow marine (Sakai 1985) whereas the presence of the mudcracks show in an arial condition. Crenulation cleavages are well developed in the phyllite along the Malekhu - Thapal Khola section. Presence of the ripple marks in the quartzite shows that the deposition was occurred in shallow depth within the neritic zone of the marine environment. The mudcracks found in the shale also suggest that the uplifted and exposed to the arial environment.

\section{Dhading Dolomite}

This formation is well exposed along the Malekhu Thopal Khola and Galchi - Kaljeri sections (Figs. 2, 3 and 4). This formation consists of well stratified, fine 


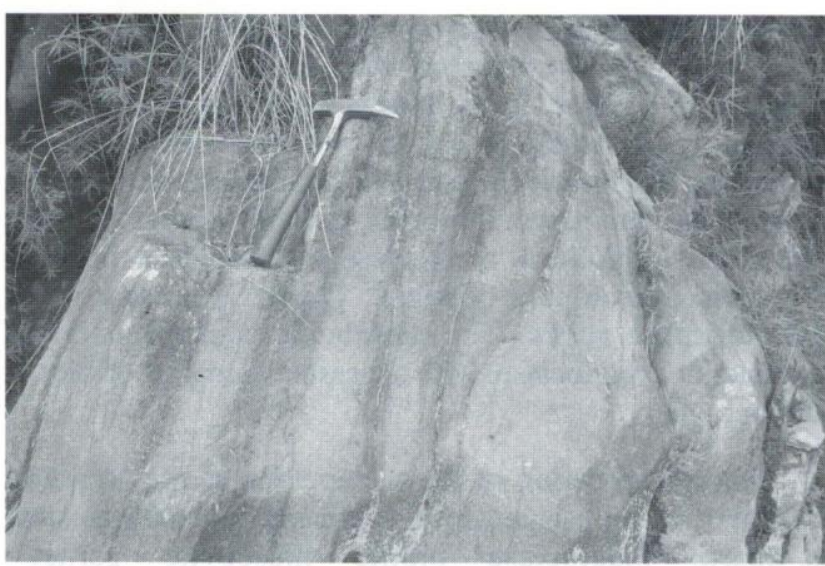

Fig. 7: Metagabbro/metabasite exposed within the phyllite of the Robang Formation along the Malekhu Khola section

crystalline, massive, fractured, grayish blue dolomite characterized by stromatolite, intercalated with fine-grained shale. Along the Malekhu-Thopal Khola section, the dome structures of the stromatolite exposed in the MalekhuDhadingbensi road section show the whole overturned strata of the area (Fig. 6b) while along the Galchi - Kaljeri section, the dome structures show the normal sequence. Stöcklin and Bhattarai (1977) observed the stromatolite in association with Lower Paleozoic algae and echinoderms along the Trishuli Valley (26 km WSW of Dhadingbensi) and $1.5 \mathrm{~km} \mathrm{~S}$ of Dhadingbensi.

At Kaljeri village, north of Galchi the contact between the Dhading Dolomite and overlying Benighat Slate is transitional marked by the alternative strata of black slate and dolomite. This transitional contact was also noted in Jajarkot - Piuthan area, west Nepal (Arita et al. 1984). But Stöcklin and Bhattarai (1977), Stöcklin (1980) observed erosional surface (unconformity) marked by abrupt lithological change with traces of laterization between the Dhading Dolomite and the Benighat Slate along the lower Burhi Gandaki Valley, a tributary of the Trishuli River. The carbonates of the Dhading Dolomite were deposited below the neritic zone of the marine environment where the calm condition of the water occurred.

\section{Upper Nawakot Group, Nawakot Complex}

\section{Benighat Slate}

This formation is well exposed along the Malekhu Thopal Khola, Galchi - Kaljeri, Phalangu Khola and Syabrubensi sections (Figs. 2, 3 and 4). This formation consists of fine-grained, more or less carbonaceous slate, grey phyllite intercalated with carbonate rocks and calcareous quartzite. Along the Phalangu Khola and Gairigaon village, northern part of the study area, metric scale of calcareous rocks is interbedded within the slate, phyllite and schist. At Syabrubensi area, this formation consists of well foliated schist, highly sheared and interfoliated with fine grained quartzite. Medium grained marble is also interfoliated within graphite-schist. Plant fossils were found from black slates in the lower Burhi Gandaki Valley (Pêcher 1977). Along the Phalangu Khola and Gairigaon village, Ulleri type augen gneisses are exposed on the top of this formation (Fig. 2). However, at Syabrubensi area, fine grained two mica-garnet schist is exposed immediate below the MCT and above the Ulleri augen gneiss. This schist also belongs to the Benighat Slate. In this area the exposure belonging to the Benighat Slate is well deformed and metamorphosed (medium to high amphibolite facies) to the schist at the proximity of the MCT. The schist contains quartz, feldspar, two mica, garnet and staurolite. However, the exposures along the Malekhu - Thopal Khola and Galchi - Kaljeri sections do not contain garnet and staurolite minerals. This formation along the Malekhu - Thapal Khola section is found to be folded with development of metric scale of anticline and syncline. The presence of the argillaceous materials of the Benighat Slate shows that deposition was formed in lower part of the neritic zone of the marine environment.

\section{Malekhu Limestone}

This formation is well exposed along the Malekhu Thopal Khola and Galchi - Kaljeri sections (Figs. 2, 3 and 4). This formation consists of thin-platy, well stratified, fine-grained, dense, yellowish-grey siliceous limestone, dark and grey colored dolomitic limestone intercalated with fine-grained, grey shale or phyllite. Parallel laminations are well preserved. Stromatolites are absent. The carbonates of the Malekhu Limestone were deposited in the lowermost part of the neritic zone and calm water condtion.

\section{Robang Formation}

This formation is well exposed along the Malekhu Thopal Khola and Galchi - Kaljeri sections (Figs. 2, 3 and 4). This formation is continuously extended to the east from Kaljeri village towards the Likhu Khola following the direction of the MCT/MT. This formation consists of finegrained, greenish-grey, greyish-white phyllite associated with grey quartzite. Few meters thick of metagabbro or metadiabasic rocks are intercalated within the phyllite and quartzite. These metagabbro or metadiabasic rocks are also well exposed in the north of Jhiltung village, north of Galchi. Along the Malekhu - Thopal Khola section (Malekhu Khola), about $50 \mathrm{~m}$ thick metagabbro or metadiabasic is interfoliated within the greenish - grey phyllite (Fig. 7). Above the metabasic rocks, the exposures of phyllite and schist are found to be well foliated, deformed due to the movement of the Mahabharat Thrust (situated at about $300 \mathrm{~m}$ south-east from metagrabboic exposure) along the Malekhu Khola. From this exposure of metagabbro, mainly schist and quartzite are alternatively exposed towards the MT. Presence of the fine-grained quartzite and argillaceous sediments indicate that the deposition was occurred in the neritic zone of the marine environment. 


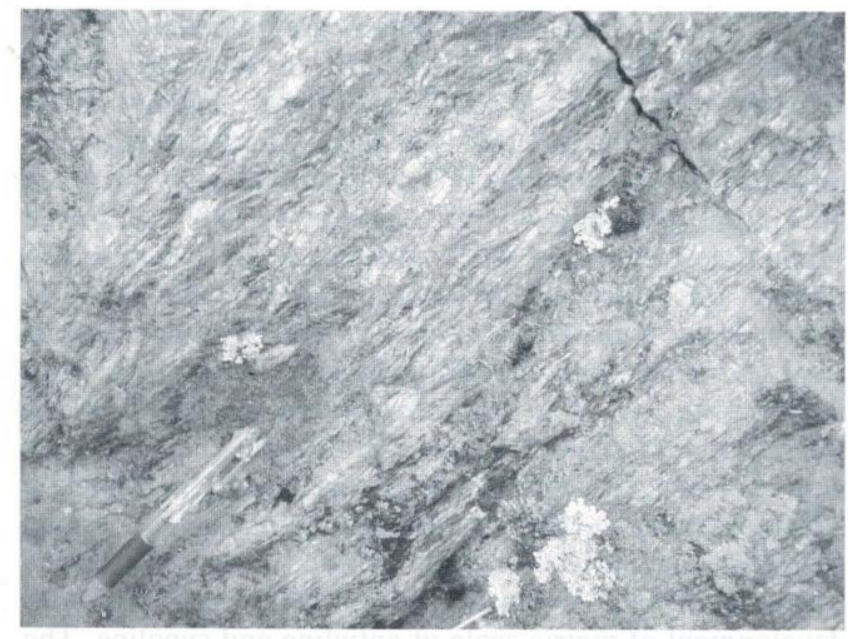

Fig. 8: Ulleri type mylonitized augen gneiss exposed at Syabrubensi area

On the uppermost section of this formation, Dunga Quartzite, a member of the Robang Formation (Stöcklin and Bhattarai 1977, Stöcklin 1980), Singla Quartzite (Le Fort 1975, Pêcher 1978, Colchen et al. 1986) is well exposed along the Malekhu Khola section, Keureni and Jhiltung villages near to the confluence of the Trishuli River and Tadi Khola, north of Galchi. This formation consists of fine-grained, greyishwhite quartzite with the intercalation of fine-grained, greenish-grey or greyish-white phyllite and schist. The rocks are more deformed at the proximity of the MCT or MT.

\section{Ulleri type augen gneiss}

This augen gneiss is well exposed along the Phalangu Khola, Gairigaon, north of the confluence of the Tadi Khola and Likhu Khola, and Syabrubensi area (Figs. 2, 4 and 8). Stratigraphically, this gneiss is exposed into two layers: (i) on the top of the Kuncha Formation (western Nepal, Le Fort 1975, Arita 1983); Taplejung area, eastern Nepal (Upreti et al. 2003) and (ii) on the upper section of the Lesser Himalaya, basically above the Benighat Slate, proximity of the MCT (Phalangu Khola, Gairigaon, north of the confluence of the Tadi Khola and Likhu Khola, and Syabrubensi area). The augen gneiss was originally acidic rock and it could be crystallized in the form of sills within the different layers of the sediments. This gneiss is mylonitized, highly sheared showing the sense of shearing from top to south. The Ulleri type augen gneiss consists of coarse-grained minerals such as quartz, K-feldspar, plagioclase, biotite and muscovite. Tourmaline, zircon and apatite are the accessory minerals.

\section{PETROGRAPHY}

The metapelites of the Nawakot Complex are represented by the chlorite to garnet $( \pm$ staurolite, \pm kyanite) zones from the lower section to the top section.
Chlorite, the main metamorphic mineral in the chlorite zone, is obliquely oriented with respect to the major foliation in phyllite. In the biotite zone, the characteristic mineral assemblages are biotite - chlorite \pm calcite in the schist. In the garnet zone, the characteristic mineral assemblages are garnet - biotite - chlorite, garnet - biotite, and garnet - biotite - plagioclase - staurolite \pm rutile in the schist and impure quartzite. Quartz is present in all metamorphic rocks. The metabasic rocks consist of hornblende, plagioclase, with accessory minerals of biotite and epidote.

The upper section of the metapelites of the Nawakot Complex is represented by the mineral assemblage such as quartz - plagioclase - biotite - muscovite - garnet staurolite \pm chlorite with accessory minerals (rutile, $\mathrm{Fe}$ Ti oxides, and tourmaline). The main foliation, related to the movement on the MCT or MT, is marked by the biotite and muscovite and some garnets contain syn-kinematic, sigmoidal inclusion trails. Traces of slight retrogression are characterized by the development of chlorite at the expense of garnet and staurolite.

Garnet porphyroblasts are euhedral to subhedral in shape. Quartz, biotite, muscovite, rutile or Fe-Ti oxides are inclusive minerals within porphyroblasts. These porphyroblasts are pre-to syn-kinematic with respect to the main foliation plane. Biotite, muscovite and chlorite crystals are euhedral to subhedral in shape and define the major foliation. Plagioclase crystals are euhedral to subhedral in shape. They are mostly parallel to the main foliation but some crystals show oblique orientation along the main foliation. Staurolite is present only in upper section of the Nawakot Complex; proximity of the MCT and it shows its euhedral to subhedral shape. It is interpreted as a syn-kinematic mineral, in textural equilibrium with garnet.

\section{DISCUSSIONS}

The Higher Himalayan Crystallines (Gosainkund Crysatlline Nappe; Rai 1998, Rai et al. 1998, Rai 2001) overlies the Lesser Himalayan Sequence (Nawakot Complex; Stöcklin and Bhattarai 1977, Stöcklin 1980) along the MCT/MT. The MT is considered as the southern continuation of the MCT in the east, south and western part of the Kathmandu Complex (Stöcklin and Bhattarai 1977, Stöcklin 1980, Pandey et al. 1995, Johnson et al. 2001). The general trend of the foliation of the Higher Himalayan Crystallines with underlying the MCT and the Lesser Himalayan Sequence (Nawakot Complex) in the northern part of study area (from Syabrubensi to Likhu Khola) is aligned from WNW-ESE to N-S direction or NNE-SSW direction and this trend of the foliation changes from the Likhu Khola to Malekhu area along the SWW-NEE direction. Langtang area is considered as the root zone of the Kathmandu Complex (Higher Himalayan Crystallines). The northern region of the Higher Himalayan Crystallines is metamorphosed to amphibolite to granulite facies rocks in the deeper zone 
while the southern part of the Higher Himalayan Crystallines (Kathmandu Complex) is considered as the shallow zone metamorphosed rocks preserved in the greenschist to lower amphibolite facies condition.

Regarding the correlation of the lithostratigraphy of the different sections of the study area, the section along the Malekhu-Thopal Khola is well exposed with all formations (Kuncha to Robang formations) from bottom to top. The rocks are well exposed along the Malekhu - Dhadingbensi road section and Malekhu Khola section. It is difficult to observe the erosional unconformity between the Lower Nawakot Group and Upper Nawakot Group due to the presence of dense vegetation in the field. All formations can be also observed along the Galchi - Kaljeri section. From north of Kaljeri village, Kuncha Formation to the Nourpul Formation can be observed in this section. Along this section, a transitional contact can be observed between the Dhading Dolomite (Lower Nawakot Group) and the Benighat Slate (Upper Nawakot Group) and no unconformity was observed as described by (Stöcklin and Bhattarai 1977, Stöcklin 1980). Along the Phalangu Khola and Syabrubensi sections, Dandagaon Phyllite, Nourpul Formation, Dhading Dolomite, Malekhu and Robang formations are not exposed and the MCT is directly rested on the Benighat Slate. However, Robang Formation (rb?) is marked just below the MCT, and bounded by a lower thrust crossing the Phalangu, Tadi and Likhu kholas (Stöcklin and Bhattarai 1977). The absence of all formations could be related with the faulting/ thrusting in the northern part of the study area. Along the Likhu Khola, Tadi Khola, Phalangu Khola and Syabrubeni sections, the rocks of the Benighat Slate are highly sheared, deformed, metamorphosed with the development of the garnet, staurolite and ( \pm kyanite) resulting amphibolite facies rocks (schist). This is resulted due to the movement of the MCT (Le Fort 1975, 1981; Pêcher 1978, 1989; Rai et al. 1998; Guillot 1999; Takagi et al. 2003). This formation contains the quartz boudins oriented mainly along the foliation plane due to movement of the MCT.

On the basis of the sedimentary structures the startigraphic sequences along Malekhu - Dhadingbensi road section, from the Kuncha Formation to Dhading Dolomite show the overturned sequences and overturned domed stromatolites also support the overturned sequences. This overturned sequence could be related to the post MCT deformational structure as the Pokhara-Gorkha anticlinorium (Pêcher 1978), Likhu Khola anticline (Rai 1998, Rai et al. 1998). Along this section from the Benighat Slate to the Robang Formation the stratigraphic sequences are normal. The normal sequences can be observed in the other sections of the study area.

\section{CONCLUSIONS}

The Malekhu - Thopal Khola and Galchi-Kaljeri sections show the exposures of all formations (Kuncha Formation from the bottom to Robang Formation on the top). The contact between the Dhading Dolomite (Lower Nawakot
Complex) and the Benighat Slate (Upper Nawakot Complex) is transitional along the Galchi -Kaljeri section. The stratigraphic sequences from the Kuncha Formation to Dhading Dolomite (Lower Nawakot Group) along the Malekhu - Thopal Khola section are overturned, showing the younger strata towards the deeper section evidenced by the sedimentary structures (ripples, mudcracks, etc) and stromatolites. These overturned sequences could be related to the development of the post MCT/MT deformational structure (Gorkha-Pokhara anticlinorium, Likhu Khola anticline). Along the Likhu Khola, Tadi Khola, Phalangu Khola and Syabrubeni sections, northern region of the study area the rocks of the Benighat Slate are highly sheared, deformed, metamorphosed with the development of the garnet, staurolite and ( \pm kyanite) due to the movement of the MCT. However, these minerals are not developed in the Robang Formation (immediate below the MT) along the Malekhu - Thapal Khola and Galchi - Kaljeri sections.

\section{ACKNOWLEDGEMENTS}

The author is grateful to the Foreign Ministry of France for providing a scholarship in Joseph Fourier University, Grenoble, France. The author is also thankful to Drs. P. D. Ulak and A. P. Gajurel for their critical review with fruitful suggestions to improve the manuscript. The author also acknowledeges Mr. G. B. Shrestha and Mr. Pramod Simkhada for their helps during the preparation of manuscript.

\section{REFERENCES}

Arita, K., Ohta, Y., Akiba, C., and Maruo, Y., 1973, Kathmandu Region. In: Geology of the Nepal Himalaya. (eds. Hashimoto, S., Ohta, Y., and Akiba, C.), Saikon Publishing Co. Ltd., Tokyo, pp. 99-145.

Arita, K., 1983, Origin of the inverted metamorphism of the Lower Himalayas, Central Nepal. Tectonophysics, v. 95, pp. 43-60.

Arita, K., Sharma, T., and Fujii, Y., 1984, Geology and structure of the Jajarkot-Piuthan areas, central Nepal. Jour. Nepal Geol. Soc., v. 4, pp. 5-27.

Colchen, M., Le Fort, P., and Pêcher, A., 1986, Recherches geologiques dans l'Himalaya du Nepal. Annapurna-ManasluGanesh du Nepal. CNRS (eds.), Paris, 136 p.

Gansser, A., 1964, Geology of the Himalaya. Wiley-Interscience, London, $289 \mathrm{p}$

Guillot, S., 1999, An overview of the metamorphic evolution in central Nepal. Jour. Asian Earth Sci., v. 17, pp. 713-725.

Inger, S. and Harris, B. W., 1992, Tectonothermal evolution of the High Himalayan Crystalline sequence, Langtang Valley, Northern Nepal. Jour. Metamorphic Geology, v. 10, pp. 439-452.

Johnson, M. R. W., Oliver, G. J. H., Parris, R. R., and Johnson, S. P., 2001, Synthrusting metamorphism, cooling, and soil erosion of the Himalayan Kathmandu Complex, Nepal. Tectonics, v. 20, pp. 394-415.

Le Fort, P., 1975, Himalaya : the collided range : Present knowledge of the continental arc. American Jour. Sci., v. 275A, pp. 1-44.

Le Fort, P., 1981, Manaslu leucogranite: a collision signature of the Himalaya. A model for its genesis and emplacement. Jour. Geophys. Res., v. 86, pp. 10545-10568. 
Macfarlane, A. M., Hodges, K. V., and Lux, D., 1992, A structural analysis of the Main Central Thrust Zone, Langtang National Park, Central Nepal. Geol. Soc. America Bull., v. 104, pp. 1389-1402.

Macfarlane, A. M., 1995, An evaluation of the inverted metamorphic gradient at Langtang National Park, Central Nepal. Jour. Metamorphic Petrology, v. 13, pp. 595-612.

Pandey, M. R., Tandukar, R. P., Avouac, J. P., Lave, J., and Massot, J. P., 1995, Interseismic strain accumulation on the Himalayan crustal ramp (Nepal). Geophys. Res. Lett., v. 22, pp. 751-754.

Paudel, L. P. and Dhital, M. R., 1996, Geology and structure of the area between Pokhara and Kusma, western Nepal Lesser Himalaya. Jour. Bull. Dept. Geology, Tribhuvan University, v. 5, pp. 47-60.

Paudel, L. P., Imayama, T., and Arita, K., 2011, Metabasites petrology and P-T evolution in the Lesser Himalaya, central Nepal. Jour. Nepal Geol. Soc., v. 42 (in the issue).

Pêcher, A., 1977, Geology of the Nepal Himalaya: deformation and petrography in the Main Central Thrust Zone. In: Ecologie et Géologie de l'Himalaya, Colloques Internationaux du Centre National de la Recherche Scientifique, Paris, v. 268, pp. 301-318.

Pêcher, A., 1978, Déformations et métamorphisme associés dans une zone de cisaillement. Exemple du grand chevauchement central himalayen (M.C.T), tranversale des Annapurna et du Manaslu, Nepal. Thesis, University of Grenoble, France, $310 \mathrm{p}$.

Pêcher, A., 1989, The metamorphism in Central Himalaya. Jour. Metamorphic Petrology, v. 7, pp. 31-41.

Rai, S. M., 1998, Les nappes de Katmandou et du Gosainkund, Himalaya du Nepal central (étude cartographique, structurale, métamorphisme, geochimique et radiochronologique). Ph. D. Thesis, Joseph Fourier University, Grenoble, France, 244 p.
Rai, S. M., Guillot, S., Le Fort, P., and Upreti, B. N., 1998, Pressure - temperature evolution in the Kathmandu and Gosainkunda regions, Central Nepal. Jour. Asian Earth Sci., v. 16. Nos. 2-3, pp. 283-298.

Rai, S. M., 2001, Geology, geochemistry, and radiochronology of the Kathmandu and Gosainkund Crystalline nappes, central Nepal. Jour. Nepal Geol. Soc. Spec. Pub., v. 25, pp. 135-155.

Sakai, H., 1985, Geology of Kali Gandaki Supergroup of the Lesser Himalayas in Nepal. Fac. Sci. Kyushu Univ., Japan. v. XXV, pp. 337-397.

Sharma, T. and Kizaki, K., 1989, Metamorphism and thermal history of the Jaljala synclinorium, central west Nepal Himalaya. Jour. Nepal. Geol. Soc., v. 6, pp. 21-34.

Stöcklin, J. and Bhattarai, K. D., 1977, Geology of Kathmandu area and central Mahabharat range, Nepal Himalaya. HMG, Nepal/UNDP report, $64 \mathrm{p}$.

Stöcklin, J., 1980, Geology of Nepal and its regional frame. Jour. Geol. Soc., London, v. 137, pp. 1-34.

Takagi, H., Arita, K., Sawaguchi, T., Kobayashi, K., and Awaji, D., 2003, Kinematic history of the Main Cental Thrust zone in the Langtang area, Nepal. Tectonophysics, v. 366, pp. 151-163.

Upreti, B. N. and Merh, S. S., 1978, Geology of the area around Bhoksing-Sirkang section of the Kaligandaki valley in Central west Nepal. Him. Geol., v. 8, pp. 797-812.

Upreti, B. N., Sharma, T., and Merh, S. S., 1980, Structural geology of the Kusma-Sirkang section of the Kaligandaki Valley and its bearing on the tectonic framework of Nepal Himalaya. Tectonophysics, v. 62, pp. 155-164.

Upreti, B. N. and Le Fort, P., 1999, Lesser Himalayan Crystalline nappes in Nepal: Problems of their origin. Geol. Soc. America., v. 328, pp. $225-238$.

Upreti, B. N., Rai, S. M., Sakai, H., Koirala, D. R., and Takigami, Y., 2003, Early Proterozoic granite of the Taplejung Window, far eastern Lesser Nepal Himalaya. Jour. Nepal Geol. Soc., v. 28, pp. 9-18. 